\title{
The Regulation of Farmer's Privilege Under Vietnamese IP Law and the Law of the European Union
}

\author{
Ho Bich Hang Nguyen • Katja Weckström Lindroos $\mathbb{D}$
}

Accepted: 11 February 2021/Published online: 30 March 2021

(C) The Author(s) 2021

\begin{abstract}
The International Union for the Protection of New Varieties of Plants Convention 1991 (UPOV Convention) recognizes the need to protect plant breeders' legitimate interests. Without breeders' innovations, new high-productivity plant varieties can neither be created nor contribute to society as a whole. Without these new varieties, it is impossible to create new high-yield generations of plants for the benefit of society. The absolute protection of breeders' rights, however, would create many negative impacts for society. In particular, farmers would have to pay higher prices for seeds if breeders' exclusive rights were to be overprotected, which would also mean consumers having to pay more for basic foodstuffs. This would lead to food insecurity nationally or even globally, in contravention of the right to food as recognized by Art. 25 of the United Nations Universal Declaration of Human Rights in 1948. These situations represent the dilemmas that governments have to cope with in developing national economies. The concept of farmer's privilege is an exemption that the UPOV Convention recognizes in order to balance benefits between breeders and farmers. Under the optional exception set out in Art. 15(2) of the UPOV Convention, Contracting Parties may adopt the farmer's privilege exemption in national law. Vietnam's Law on Intellectual Property contains
\end{abstract}

This article is produced within the framework of the Fraud-Free Food and Regulatory Knowhow (FORK)-project funded by the Academy of Finland and the University of Eastern Finland. LL.D. Nguyen is primarily responsible for the sections on Vietnamese law and its interpretation. Professor Lindroos is primarily responsible for the section on EU law and its interpretation.

\footnotetext{
H. B. H. Nguyen

LL.D., University Lecturer at UEF Law School, Joensuu, Finland and Lecturer at Ho Chi Minh City University of Law, Ho Chi Minh City, Vietnam

e-mail: hang.nguyen@uef.fi
}

K. Weckström Lindroos $(\bowtie)$

Prof., docent, LL.D., Professor of Commercial Law, UEF Law School,

University of Eastern Finland, Joensuu, Finland

e-mail: katja.lindroos@uef.fi 
the farmer's privilege exemption, yet there are many loopholes regarding this provision, and in reality, its application is limited. This article analyzes European Union regulation on farmer's privilege and the way in which this exception has been interpreted, and compares and applies it to the Vietnamese law.

Keywords Plant variety protection - Farmer's privilege · UPOV convention • EVFTA $\cdot$ CPVR $\cdot$ US-Vietnam BIT $\cdot$ CPTPP · WTO TRIPS

\section{Legal Framework of Farmer's Privilege Under the UPOV Convention}

\subsection{Farmer's Privilege Exemption}

The UPOV Convention ${ }^{1}$ establishes a sui generis legal framework for its Contracting Parties on the protection of newly invented plant varieties. ${ }^{2}$ This helps small breeders and biotech developers to increase market access as it reduces the costs and time involved in accessing overseas markets. ${ }^{3}$ The UPOV Convention's objective is to provide and promote an effective system of plant variety protection in order to encourage the development of new varieties of plants, for the benefit of society as a whole. ${ }^{4}$ Without breeders' innovations, new high-productivity plant varieties can neither be created nor contribute to society. ${ }^{5}$ Furthermore, the Convention aims to encourage plant breeding among the Contracting Parties. ${ }^{6}$ While the UPOV Convention protects breeders' rights, it also allows farmers to save seeds for the next crop on their own land. This right to plant self-saved seeds is also known as "farmer's privilege" exemption. Farmer's privilege is a crucial regulatory tool that allows a balance to be struck between the rights of farmers and breeders, albeit that the UPOV Convention is seen as providing a model of protection mostly focused on breeders' commercial interests. ${ }^{7}$ The existence of farmer's privilege facilitates the recognition of the long-term investment of farmers and communities in genetic resources, ${ }^{8}$ and this privilege reflects the "contribution of farmers in all regions of the world, particularly those in centers of origin and diversity, in conserving, improving and making available these resources." 9

\footnotetext{
1 The International Union for the Protection of New Varieties of Plants Convention 1991 (hereinafter UPOV Convention).

2 Martin Ekvad (2018), p. 309.

${ }^{3}$ WTO, Review of the provisions of Art. 27.3.(B) Summary of issues raised and points made, noted by the Secretariat IP/C/W/369/Rev.1, 9 March 2006, p. 61.

${ }^{4}$ UPOV, Mission Statement, available at http://www.upov.int/about/en/mission.html (accessed 5 May 2020).

5 Niels Louwaars et al. (2009), "Breeding business: the future of plant breeding in the light of developments in patent rights and plant breeder's rights," Centre for Genetic Resources, the Netherlands, Wageningen University and Research Center, p. 14.

6 Jay Sanderson (2017), p. 265.

7 Carlos M. Correa (ed.) (2015), p. ix.

8 Maria Lee (2008), p. 159.

9 Recitals to the International Treaty on Plant Genetic Resources of Food and Agriculture (Food and Agriculture Organization, 2001).
} 
However, the local tradition of farmers trading and exchanging seeds is not allowed under the UPOV Convention in respect of seeds under plant variety protection. Absolute protection of breeders' rights might give rise to adverse impacts on national targets linked to food security, health and the country's rural development. ${ }^{10}$ This could lead to food insecurity nationally or even globally, in contravention of the right to food as recognized by Art. 25 of the United Nations Universal Declaration of Human Rights in 1948. ${ }^{11}$ Article $15(2)$ of the UPOV Convention, on the farmer's privilege reads as follows:

... each Contracting Party may, within reasonable limits and subject to the safeguarding of the legitimate interests of the breeder, restrict the breeder's right in relation to any variety in order to permit farmers to use for propagating purposes, on their own holdings, the product of the harvest which they have obtained by planting, on their own holdings .....$^{12}$

When joining the Convention, countries have the right to implement its provisions within their domestic legal systems, especially in relation to the optional provisions. Farmer's privilege is a flexibility clause in the Convention, meaning that the Contracting Parties have discretion over whether to take advantage of it. Many of the Contracting Parties are developing countries, whose economies are strongly dependent on agriculture. Consequently, agricultural policies related to seeds are crucial to their development.

In order to clarify Art. 15(2) of the UPOV Convention on farmer's privilege, the UPOV Explanatory Notes ${ }^{13}$ emphasize that Contracting Parties are not obligated to incorporate it in their national laws. In explaining the word optional, the UPOV Explanatory Notes recommend that Art. 15(2) "should not be read so as to be intended to open the possibility of extending the practical commonly called farmer's privilege, to sector of agricultural or horticultural production in which such a privilege is not a common practice on the territory of the Contracting Party concerned."14 This explanation of Art. 15(2) seems to interfere with the freedom of Contracting Parties to decide what harvested material farmers can keep for further propagation. This issue is best left for national regulation on the part of the Contracting Parties, especially considering national strategies for plant structure, which vary by season and region. Developing countries should take advantage of the flexibility provided for in Art. 15(2) to benefit their farmers. Therefore, whether Contracting Parties recognize the farmer's privilege exemption in their national laws is their prerogative. Farmer's privilege under the UPOV Convention means that farmers can save protected varieties of seeds and replant them on their own holdings, subject to certain conditions related to seed variety and farm size.

\footnotetext{
${ }^{10}$ WTO (supra note 3), p. 46.

11 Universal Declaration of Human Rights, Art. 25(1).

12 UPOV Convention, Art. 15(2).

13 Explanatory notes on exceptions to the breeder's right under the UPOV Convention adopted by the Council at its forty-third ordinary session on October $22^{\text {nd }}, 2009$ (hereinafter UPOV Explanatory Notes).

14 UPOV Publication No. 346 (E), p. 63.
} 


\subsection{Purpose of Using Self-Saved Seeds}

The purpose of Art. 15(2) of the UPOV Convention is to balance the benefits of the breeders and farmers. This provision grants farmers the right to save their seeds for propagation on their holdings, but seed-saving for other purposes than propagation (i.e. exchange, share, trade, gift) is not allowed or recognized. Farmer's privilege under the UPOV Convention does not allow farmers to exchange with others propagating material that they have harvested. Farmers can use seeds from crops harvested on their own holdings for propagating purposes. This provision aims to eliminate the circulation of seeds among farmers and to protect the breeders' rights set out in Art. 15(2) as expressed in the wording "subject to the safeguarding of the legitimate interests of the breeders." This also means that the sale or exchange of saved seeds of protected varieties among farmers are viewed as infringing breeders' rights.

The purpose of using self-saved seeds is linked with the challenges present in developing countries, where seed networks form part of farmers' agricultural traditions. The term "farmer seed network" refers to the "transfer [of] seed from domesticated or undomesticated plants via farmer-to-farmer gifting, swapping, [or] bartering." 15 The propagation material that flows through networks come from farmers, local markets, as well as from international bodies such as NGOs and foundations. ${ }^{16}$ The custom of utilizing seed networks among farmers has existed for generations in developing countries. Changing it will take time because, ultimately, farmers will decide if they wish to transfer or save seeds according to the circumstances at hand.

The way in which self-saved seeds are used is critical in terms of limiting farmers' rights in countries where many farms have substantial acreage, as in many European countries. Where large scale farms are involved, if farmers are allowed to trade or exchange harvested materials, the economic rights of right holders will be seriously impacted - and farmers are well aware of the intellectual property rights involved. On the other hand, farmers in developing countries may not be aware of these rights or of the need to protect plant varieties, and this is particularly true of smallholders. ${ }^{17}$ For that reason, the economic impact on breeders' rights is less serious in the developing countries than in developed nations.

The protection of plant varieties assists the development of new technological solutions in the field of agriculture and allows breeders to continue breeding effectively. ${ }^{18}$ For that reason, there would be no incentive for breeders if their results were not appropriately recognized or protected. The self-saved seeds exemption offers a reasonable solution in terms of its balance with breeders' rights so long as the benefits accorded to the parties remain in balance. It is reasonable for farmers to be able to save seeds for further propagation on their private holdings for

\footnotetext{
15 Oliver T. Coomes et al. (2015), pp. 41-50.

16 Ibid.

17 Noluthando C. Netnou-Nkoana et al. (2015), pp. 1-5.

18 WTO (supra note 3), p. 45.
} 
the next season. However, this exemption is only accepted so long as the farms are not recognized as "large scale" ones.

\subsection{Farm Size}

Farm size is one of the conditions that must be met in order to ensure breeders' legitimate benefits are preserved. ${ }^{19}$ The farmer's privilege exemption in the UPOV Convention means farmers have the right to save seeds of protected varieties for their own use. It should be kept in mind that this means farmers are allowed "to use for propagating purposes, on their own holdings, the product of the harvest which they have obtained by planting, on their own holdings." ${ }^{20}$ What is the legitimate amount of seeds that can be saved as propagating material? Article 15(2) of the UPOV Convention does not explicitly address this issue in quantitative terms, but it can be understood as meaning as much as a farmer needs for his or her own holdings. Nevertheless, this rule cannot apply in all circumstances, as it also depends on the size of the farm. Although the UPOV Convention is unclear on this issue, its Explanatory Notes provide detailed guidance.

The UPOV Convention does not indicate the size of the holdings or the amount of harvested crop that farmers can save from their own holdings, nor suggest any specific maximum farm size. These are elements that affect the economic interests of the breeder, and concern the size of a farmer's holding, the farmed area of the crop concerned and the value of the harvested crop. ${ }^{21}$ The Explanatory Notes indicate that farmer's privilege is only to be removed where "large farms" are concerned. Medium-sized and small farms are therefore not caught by this condition. ${ }^{22}$ The definition of farm size as small or otherwise depends not only on calculation of the acreage per se but also on national policy from one period to another. Furthermore, plant species is also an element to consider in relation to farm size.

For that matter, each Contracting Party to the UPOV Convention should determine holding size depending on the situation on the ground at the national level at the relevant time in respect of the seed variety in question. The Explanatory Notes indicate that Contracting Parties should regulate and define the relevant crop area in their jurisdictions. By limiting the size of holdings, the amount of farm-saved seeds utilized will also be limited, and breeders' legitimate interests will be protected effectively. In order for farmers' legitimate benefits to be safeguarded, each nation needs to have in place a satisfactory means of evaluating farm size that is appropriate in view of the geographical conditions of the country, and which also safeguards breeders' economic rights. The UPOV Contracting Parties can learn from the European Union (EU) concerning this issue.

\footnotetext{
19 Correa (supra note 7), p. 35.

${ }^{20}$ UPOV Convention, Art. 15(2).

21 UPOV Explanatory Notes, para. 22.

22 Ibid.
} 


\subsection{Types of Seed Variety}

The farmer's privilege exemption under the UPOV Convention can only be employed for certain types of seed variety. The Explanatory Notes state that in respect of the limitation on seed type "for a particular crop or species, it is possible to specify only certain types of varieties for which the optional exception [is] to be applicable." This means that "authorities might decide not to extend the optional exception to certain types of varieties, e.g. hybrid varieties or synthetic varieties." 23

Hybrid or synthetic varieties are created by combining genotypes as provided in Art. 1(vi) of the UPOV Convention and further specified in the UPOV Explanatory Notes on the definition contained in Art. 1(vi). ${ }^{24}$ The purpose of excluding hybrid or synthetic varieties from the list of exceptional cases may stem from the expense incurred by breeders in creating these varieties. However, this explanation is unnecessary from a biotechnological perspective. As a matter of fact, "plants grown from hybrid varieties usually do not produce seeds that can be grown for the next crops and can even produce seeds that will not be able to grow." 25 In fact, in many countries, most of the seeds that ensure a good yield are hybrid, and farmers' experience has been that "saved seed did not produce good quality product." 26 Consequently, the limitation of hybrid varieties does not make much sense from a practical point of view.

In addition, according to the UPOV Explanatory Notes, a Contracting Party can, through its domestic laws, decide to introduce the optional exception for certain types of plant varieties for which the optional exception would be applicable ${ }^{27}$ rather than just hybrid or synthetic varieties. In other words, at any time, in view of its own circumstances, a country is entirely within its discretion as to whether specific crops or varieties fall under farmer's privilege or not. Notably, the authorities in such situations have to take into consideration whether saving propagation material for the next crop in that territory is a common practice among farmers, and to balance the legitimate rights and benefits of the related parties in such a situation. The type of variety issue should, therefore, be governed by Contracting Parties, depending on their agricultural domestic conditions. Contracting Parties should enlarge the scope of crop types from which seed is saved because this exemption does not only apply to seeds but also to vegetatively propagated crops. ${ }^{28}$ As the UPOV Convention leaves wide policy space for its Contracting Parties to decide on this issue, it is significant for developing countries to take advantage of the unused policy space to support their domestic agricultural sector.

The farmer's privilege exemption cannot be applied for all the crops in the territory of a Contracting Party if that nation has recognized this exemption in its law. The UPOV Explanatory Notes recommend that "the optional exception was

\footnotetext{
23 Ibid., para. 19.

24 Ibid.

25 Mrinalini Kochupillai (Kochupillai 2016), p.125.

26 Netnou-Nkoana (supra note 17), p. 3.

27 UPOV Explanatory Notes, para. 19.

${ }^{28}$ Netnou-Nkoana (supra note 17), p. 2.
} 
aimed at those crops where, for the member of the UPOV Convention concerned, there was a common practice of farmers saving harvested material for further propagation." 29 This explanation narrows down the crops that farmers can propagate. Furthermore, "it may be considered inappropriate to introduce the optional exception for agricultural or horticultural sectors, such as fruits, ornamentals, and vegetables, where it has not been a common practice for the harvested material to be used as a propagating material." 30 This explanation may make sense in theory when it seeks to find a balancing point that harmonizes the benefits of the related parties in the plant variety protection relationship. Unfortunately, what happens in reality may be the opposite. Farmers can use crop diversity to decrease the incidence and impact of plant pests and diseases. ${ }^{31}$ In order to avoid or reduce problems with soil-borne disease as well as soil dilution, farmers rotate crops from time to time. For that reason, the limitation aimed at "crops where there was a common practice of saving harvested material for further propagation" does not fit with the practical situation.

\section{Farmer's Privilege Under EU Law}

\subsection{IPR Protection and Legitimate Interests}

Regulation (EC) No 2100/94 on Community plant variety rights (the "Basic Regulation") governs issues related to the protection of plant varieties in the EU based on the UPOV Convention. ${ }^{32}$ The Basic Regulation established a system granting EU-wide intellectual property rights, known as Community Plant Variety Rights (CPVRs), in respect of new plant varieties. Once granted, a CPVR is valid in all EU Member States. The CPVR system exists parallel with national plant variety protection schemes. ${ }^{33}$ However, CPVR protection cannot be combined with national protection or a patent. ${ }^{34}$ Thus, while it is possible to obtain a patent on plant-related inventions, ${ }^{35}$ it is not possible to hold both a CPVR and patent in relation to the

\footnotetext{
29 UPOV Explanatory Notes, para. 14.

30 Ibid., p. 9.

31 Michael Halewood and Isabel Lapeña (2016), p. 1.

32 Council Regulation (EC) No 2100/94 of July 1994 on Community plant variety rights, OJ L 227/1.

33 Basic Regulation, Art. 3.

34 Ibid., Arts. 1 and 92. The European members of the WTO have interpreted the obligation under Art 27.2 of the TRIPS Agreement as being primarily a requirement to provide a sui generis regime for plant variety protection. The CPVR regime, excluding simultaneous patent protection, is binding on all EU Member States. The European Patent Convention is not subject to EU law. However, all of its members that are EU Member States may offer patent protection for plant-related inventions only to the extent that this is not limited by CPVR. See the recitals to the Basic Regulation.

35 Patent protection for plant-related inventions is not limited to the object of plant varieties as defined in the context of the CPVR (See, e.g. the European Patent Convention, Art. 53(b)). However, plant breeding methods and plants created using these methods (essentially biological processes) are generally excluded from patent protection. See, e.g. European Patent Convention, Arts. 53(b) and 64(2) and the European Patent Office Guidelines, at 5.4.1, available at https://www.epo.org/law-practice/legal-texts/html/ guidelines/e/g_ii_5_4_1.htm (accessed 5 February 2020).
} 
same new plant variety. Under the Basic Regulation, a plant variety must be distinct, uniform, stable and new in order to be eligible for protection. In addition, the variety must be designated by a denomination that does not conflict with existing national or CPVR denominations. ${ }^{36}$ The conditions for protectable varieties in the EU are identical to the conditions for protection laid down in Art. 5 of the UPOV Convention.

The holder of a CPVR can prevent any individual or organization from producing, reproducing, conditioning for the purpose of propagation, offering for sale, selling, exporting, importing, or stocking the protected plant variety without permission during the term of protection. ${ }^{37}$ The term of protection for CPVRs is 25 years, and 30 years for vines and tree varieties. ${ }^{38}$ The right holder can set conditions and limitations concerning authorization. However, the scope of this right has been subject to interpretation in the case law of the Court of Justice of the European Union (CJEU). ${ }^{39}$ Article 14 of the Basic Regulation limits CPVR rights as follows:

... [F]or the purposes of safeguarding agricultural production, farmers are authorized to use for propagating purposes in the field, on their own holding the product of the harvest which they have obtained by planting, on their own holding, propagating material of a variety other than a hybrid or synthetic variety, which is covered by a Community plant variety right. ${ }^{40}$

The conditions for the exemption are laid down in Art. 14(3) and further clarified by Regulation (EC) No 1768/95 (the "Implementing Regulation"). ${ }^{41}$ In the UPOV Convention, farmer's privilege is recognized as an exception, which is applied as long as the legitimate interests of breeders are safeguarded. ${ }^{42}$ While farmers' legitimate interests are not mentioned in the UPOV Convention, the Implementing Regulation explicitly states that rules must be "implemented both by the holder, representing the breeder and by the farmer in such a way as to safeguard the legitimate interests of each other." 43 In the EU, a farmer's legitimate interests are not considered safeguarded "if one or more of these interests are adversely affected without account being taken of the need to maintain a reasonable balance between all of them, or of the need for proportionality between the purpose of the relevant condition and the actual effect of the implementation thereof." 44 This provision seeks to balance the interests of all related parties: the question of how this is to be

\footnotetext{
36 Basic Regulation, Arts. 6 and 63.

37 Ibid., Art. 13.

38 Ibid., Art. 19.

39 C-509/10 - Geistbeck, ECLI:EU:C:2012:416; and C-242/14 - Saatgut-Treuhandverwaltung, ECLI:EU: $\mathrm{C}: 2015: 422$.

40 Basic Regulation, Art. 14(1).

41 Commission Regulation (EC) No 1768/95 of 24 July 1995 implementing rules on the Agricultural exemption provided for in Article 14(3) of Council Regulation (EC) No 2100/94 on Community plant variety rights, OJ L 173/14.

42 UPOV Convention, Art. 15(2).

43 Implementing Regulation, Art. 2(1).

44 Ibid., Art. 2(2).
} 
done arises when a claim of infringement of CPVR rights is brought. The achievement of balance hinges on the way in which the CJEU interprets the concept of "equitable remuneration." 45

\subsection{Purpose of Exempting Self-Saved Seeds}

The exemption allows farmers the right to use products of their own harvests for propagating purposes, in fields on their own holdings, to safeguard agricultural production. ${ }^{46}$ It does not cover hybrid varieties, nor trade or exchange for free which constitute transfer of ownership. The use of self-saved seeds is lawful if a farmer pays "equitable remuneration" to the right holder of the protected plant varieties. ${ }^{47}$ Absent such payment, the farmer is liable for infringement and must pay "reasonable compensation" under Art. 94 of the Basic Regulation.

In Saatgut-Treuhandverwaltung, the defendants argued that the exemption in Art. 14 of the Basic Regulation allowed the use of self-saved seeds without compensation, or at least, barred compensation higher than "equitable remuneration." STV, representing the interests of several plant variety right holders including the variety "Finita," which the defendants propagated from without the prior authorization of the right holder. The defendants did not pay equitable remuneration despite this being requested by STV. The question that arose was whether the defendants could rely on farmer's privilege if infringement had occurred.

In this context, it should be noted that the amount of equitable remuneration is lower than reasonable compensation, as it must be sensibly lower than the amount charged for the licensed production of propagating material of the same variety in the same area. The basis for calculating "reasonable compensation" for infringing use is equivalent to the regular license fee. ${ }^{48}$ The defendants' arguments were rejected on the basis that they could not benefit from trying to evade detection. ${ }^{49}$ While farmers are not obligated to enter into a contract with the plant variety holder or pay for use in advance, the CPVR holder is entitled to rely on good faith cooperation with farmers. ${ }^{50}$ Thus, farmers must pay remuneration by the end of the marketing year in which they planted the self-saved seed. ${ }^{51}$ After this period, the right holder can initiate infringement proceedings, which carry an obligation to pay the full license fee. ${ }^{52}$ Any other ruling would render the CPVR right useless. ${ }^{53}$ Allowing recourse to farmer's privilege would also allow a benefit to be granted to farmers that evade payment over those that comply with CPVR rules by paying

\footnotetext{
45 C-509/10 - Geistbeck, para. 30, citing the Opinion of the Advocate General at paras. 45 and 47.

46 Basic Regulation, Art 14(1).

47 Ibid., Art. 14(3).

48 C-242/14 - Saatgut-Treuhandverwaltung, para. 22.

49 Ibid., para. 28.

50 C-509/10 - Geistbeck, para. 42; and C-242/14 - Saatgut-Treuhandverwaltung, para. 29

51 C-242/14 - Saatgut-Treuhandverwaltung, para. 51.

52 Ibid., para. 31.

53 Ibid., para. 28, citing the Opinion of the Advocate General at 39.
} 
remuneration. ${ }^{54}$ Therefore, it is not possible to fix the amount of reasonable compensation to a specific license fee, since circumstances between farmers may differ. $^{55}$ If the infringement is intentional or negligent, the farmer is liable for damages. 56

Thus, farmers can use self-saved seeds for the right purpose under the UPOV Convention and the Basic Regulation. However, if they fail to meet their financial obligation, they can be considered as having infringed the plant variety rights.

\subsection{Farm Size}

The UPOV Convention does not lay down specific requirements on the size a farm needs to be in order to benefit from farmer's privilege. It is within national discretion to decide whether to exempt uses based on the size of the farm and to do so in a manner that fits the practical situation in a given country. Farm size varies greatly due to the variety of natural geographical conditions throughout the EU. The Basic Regulation prohibits the setting of a quantitative restriction, above which farmer's privilege becomes unavailable, on the basis of the size of the farmer's holding. ${ }^{57}$ However, farmers may have different obligations depending on whether or not their farms can be classified as "small": small farmers are not obligated to pay remuneration to rights holder, while other farmers are required to perform their financial obligations. ${ }^{58}$

Under the Basic Regulation, a farm is considered to be small when it does not grow plants on an area larger than that needed to produce 92 metric tons of cereals per harvest. This condition only applies in respect of fodder plants, cereals, potatoes and oil and fiber plants listed in Art. 14(2). Of farmers that grow potatoes, small farmers are those who do not grow them on an area bigger than that needed to produce 185 metric tons of potatoes per harvest. ${ }^{59}$ In order to be considered a small farm for the purposes of propagating self-saved seed, the relevant areas are those where the plant in question is grown, not including areas where other plants are grown. However, a time limit is included, and self-saved seeds cannot be planted for more than five years without compensation. ${ }^{60}$

Each Member State authority is to calculate the limits based on the average yield and conditions in their territory to define the area that qualifies as small cultivation for this purpose. ${ }^{61}$ In the event of a dispute, the farmer must prove that it satisfies the

\footnotetext{
54 C-509/10 - Geistbeck, paras. 34 and 41.

55 C-242/14 - Saatgut-Treuhandverwaltung, para. 22.

56 C-509/10 - Geistbeck, para. 15; and C-305/00 - Schulin, ECLI:EU:C:2003:218, para. 71.

57 Basic Regulation, Art. 14(3), first indent.

58 Basic Regulation, Art. 14(3).

59 Implementing Regulation, Art. 7(3).

60 Ibid.

61 Ibid., Art. 7(4).
} 
requirements of a small farm. ${ }^{62}$ Thus, all farmers are required to provide information on plants grown upon request of the plant variety holder. ${ }^{63}$

This shows the flexibility of the Basic Regulation as compared to the UPOV Convention.

\subsection{Types of Variety}

The Basic Regulation lists only certain types of plant species namely fodder plants, cereals, potatoes and oil and fiber plants (in Art. 14(2)). Hybrid and synthetic varieties of these plant species are excluded from the exemption. ${ }^{64}$ Thus, farmers that plant propagating material from other plant species cannot rely on farmer's privilege. $^{65}$

Farmers can only keep the propagating material of a variety for planting on their own holding in the next crop. In practice, if hybrid or synthetic seeds were used as propagating material, the yield will be minimal due to their biological characteristics. It is less costly for farmers to buy new seeds at market price than to replant saved hybrid or synthetic seeds. For that reason, there is no need to apply the exception to hybrid or synthetic varieties.

Nonetheless, there may be an interest in preserving certain plant varieties, which may impact farmer's rights. In Association Kokopelli ${ }^{66}$ this issue was raised in relation to a conflict between the International Treaty on Plant and Genetic Resources for Food and Agriculture (ITPGRFA) and EU legislation. The ITPGRFA obligates its members to integrate conservation and sustainable use of plant genetic resources for food and agriculture into their agricultural policy. ${ }^{67}$ In response to this obligation, EU law provides for a common catalogue of vegetable seeds that are not subject to marketing restrictions in the EU. ${ }^{68}$ Varieties that are distinct, stable and uniform may be included in the common catalogue. ${ }^{69}$ Varieties that are traditionally grown in particular localities and regions and threatened by genetic erosion (conservation variety) may be exempted from the requirement of official examination. ${ }^{70}$ In Association Kokopelli reference was made to Art. 9 of the ITPGRFA, which mentions "local and indigenous communities and farmers" and states that the Article cannot be interpreted as limiting "any rights that farmers have to save, use, exchange and sell farm-saved seed/propagating material, subject to national law as appropriate." Association Kokopelli is a non-profit-making association that sells the seeds of old vegetable and flower varieties originating from organic agriculture and

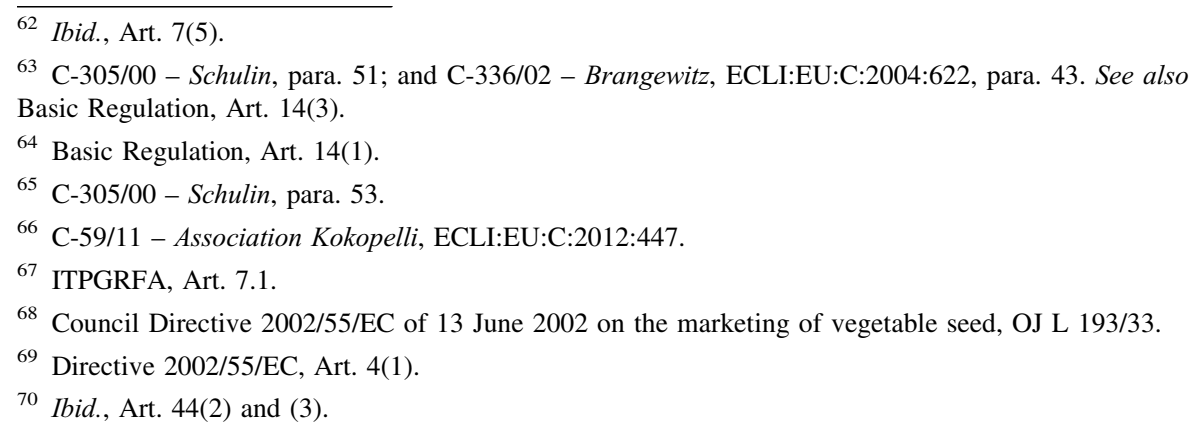


supplies its members with vegetable varieties that are not widely cultivated in France. The court held that Art. 9 of the ITPGRFA was insufficiently precise to provide a basis on which to challenge the validity of EU law. ${ }^{71}$

Thus, instituting an acceptance regime for cataloguing varieties and requiring that certain standards must be adhered to when varieties are sold without market restrictions may have substantial adverse consequences for certain traders. The EU legislator was, however, within its right to frame its agricultural policy to ensure a high level of agricultural production that is of good quality, reliable and maintained over time. These interests may be balanced against the legitimate interest in conservation and sustainable use of traditional plant varieties. ${ }^{72}$ The imposition of geographical, quantitative and packaging restrictions for conservation varieties is also appropriate in order to prevent the emergence of a parallel market for seeds of protected vegetable varieties. ${ }^{73}$ It is within the discretion of the EU legislator to change this legislative stance.

\section{Legal Provisions on the Protection of Plant Varieties and Farmer's Privilege in Vietnam}

\subsection{Legal Obligations Relating to the Protection of Plant Varieties in Vietnam}

\subsubsection{The Current Situation Concerning Creation of New Plant Varieties in Vietnam}

Given the lack of technological and financial investment in the agricultural sector in Vietnam, relatively few domestic individuals or organizations have the capacity to create new types of plant varieties. Farmers have to pay high prices to import seeds from overseas. In fact, annually Vietnam imports approximately 80 to $95 \%$ of the total amount of seeds required to meet domestic needs. There is a very high risk of dependency on imported seed in the domestic agricultural sector. ${ }^{74}$ When imported plant varieties are in the majority of seeds grown in a developing country, the result is to "narrow down the genetic diversity in the fields." 75 Furthermore, local or regional indigenous seeds may disappear if imported seeds become popular. The biological conversion of certain plant varieties that are significant in Vietnam will affect the ecosystem of a locality, region or even the entire country.

\footnotetext{
71 Directive 2002/55/EC and Commission Directive 2009/145/EC of 26 November 2009 providing for certain derogations, for acceptance of vegetable landraces and varieties which have been traditionally grown in particular localities and regions and are threatened by genetic erosion and of vegetable varieties with no intrinsic value for commercial crop production but developed for growing under particular conditions and for marketing of seed of those landraces and varieties, OJ L 312/44.

72 C-59/11 - Association Kokopelli, paras. 40, 45 and 58.

73 Ibid., paras. 65 and 72.

74 Hoàng Phạm, Nông nghiệp Việt trước nguy cơ lệ thuộc nguồn giống nhập kh u [Vietnamese agriculture in danger of dependence on imported seed source], available at http://cand.com.vn/Kinh-te/ Nong-nghiep-Viet-truoc-nguy-co-le-thuoc-nguon-giong-nhap-khau-459130/ (accessed 5 March 2020).

75 Correa (supra note 7), p. ix.
} 
In order to create new species of seeds or plant varieties Vietnam must enact more suitable policies to encourage and support domestic individuals and organizations in relation to agricultural research and development activities. This is the only means available to help Vietnam gradually become more active in producing seeds for domestic uses and reduce its dependence on imported seeds. The past three decades have witnessed changes in Vietnam's legal environment, especially in terms of regulating the protection of new plant varieties. The Law on Intellectual Property ${ }^{76}$ was enacted, and the country has joined many bilateral and multilateral trade agreements in order to boost its agricultural sector. Vietnam's efforts in protecting its plant varieties are aimed at developing the national economy and competing with other agricultural exporting countries in the Southeast Asia region, such as Thailand, Malaysia and Indonesia. A chart shows the important legal instruments related to protection of plant varieties that Vietnam has issued and/or ratified to date (Table 1).

\subsubsection{The United States-Vietnam Bilateral Trade Agreement}

In 2000, Vietnam entered into a bilateral trade agreement (BTA) with the United States (US) (the US-Vietnam BTA"), ${ }^{77}$ which marked a milestone in Vietnam's history as it normalized economic relations between the two countries. This bilateral agreement has significantly impacted Vietnam in terms of creating more jobs, income and investment opportunities for its people. More importantly, it has helped Vietnam open the door to doing business with the rest of the world. The USVietnam BTA is based to a large extent on WTO Agreements, with extensive obligations regarding the protection of intellectual property rights. ${ }^{78}$ Chapter II of the US-Vietnam BTA reads as follows:

... The exclusion for plant varieties is limited to those plant varieties that satisfy the definition provided in Article 1(vi) of the UPOV Convention (1991). ... The exclusions for plants and animal varieties shall not apply to plant or animal inventions that could encompass more than one variety. Moreover, the Parties shall provide for the protection of plant varieties by an effective sui generis system ... ${ }^{79}$

In consideration of the impact of the TRIPS Agreement ${ }^{80}$ on the need to protect plant varieties, the US-Vietnam BTA refers to "an effective sui generis system" in a similar manner to the wording contained in Art. 27.3(b) of this Agreement. By setting a requirement on the provision of an adequate protection regime for plant

\footnotetext{
76 The Law on Intellectual Property Law 2005 (hereinafter the IP Law) entered into force on 1 July 2006. A number of its articles were amended in 2009 and 2019.

77 The US and Vietnam normalized their economic relations with the coming into effect of the USVietnam Bilateral Trade Agreement on December 10, 2001.

78 Parker et al. (2002), p. 199

79 US-Vietnam BTA, Chapter II, Art 7(2)(C).

${ }^{80}$ The Agreement Trade-Related Aspects of Intellectual Property Rights (TRIPS Agreement) is an international legal agreement between all the members of the WTO.
} 
Table 1 Farmer's privilege exemption and international obligations under current Vietnamese law

\begin{tabular}{|c|c|c|c|c|c|c|}
\hline Year & 2000 & 2005 & 2006 & 2007 & 2019 & 2020 \\
\hline Name & $\begin{array}{l}\text { US- } \\
\text { Vietnam } \\
\text { BTA }\end{array}$ & IP Law & $\begin{array}{r}\text { UPOV } \\
1991\end{array}$ & $\begin{array}{l}\text { WTO } \\
\text { (TRIPS) }\end{array}$ & СРТРР & EVFTA \\
\hline \multirow{3}{*}{$\begin{array}{l}\text { Mechanism(s) relating to } \\
\text { protected plant varieties }\end{array}$} & & & & Patent & & \\
\hline & sui generis & $\begin{array}{l}\text { sui } \\
\text { generis }\end{array}$ & $\begin{array}{l}\text { sui } \\
\text { generis }\end{array}$ & $\begin{array}{l}\text { sui generis } \\
\text { system }\end{array}$ & $\begin{array}{l}\text { sui } \\
\text { generis }\end{array}$ & $\begin{array}{l}\text { sui } \\
\text { generis }\end{array}$ \\
\hline & & & & $\begin{array}{l}\text { Any } \\
\text { combinatio }\end{array}$ & & \\
\hline $\begin{array}{l}\text { Farmer's privilege } \\
\text { exemption }\end{array}$ & $\begin{array}{l}\text { Not } \\
\text { mentioned }\end{array}$ & Yes & Yes & $\begin{array}{l}\text { Not } \\
\text { mentioned }\end{array}$ & Yes & Yes \\
\hline
\end{tabular}

National legislation and international agreements in force in Vietnam

varieties, the US wanted to protect its investors when doing business in Vietnam in the agricultural sector. The US-Vietnam BTA gave Vietnam a springboard to officially join the UPOV Convention in 2006 and the WTO in 2007. However, the US-Vietnam BTA does not include the farmer's privilege exemption.

\subsubsection{Vietnam's IP Law}

When the IP Law was enacted in 2005, Vietnam was in the final stage of negotiations to become a member of the UPOV Convention and the WTO. For that reason, its domestic regulations have to comply with the international obligations laid down in the regional and global trade pacts. By recognizing an independent regime to protect plant varieties in the IP Law, Vietnam has demonstrated efforts to meet its obligations concerning the protection of plant varieties as a subject matter of intellectual property rights. The IP Law protects plant varieties via the sui generis system it lays down.

This sui generis system grants exclusive rights to individuals or organizations that select, discover, develop or invest in the selection and breeding or the discovery and development of plant varieties. ${ }^{81}$ Nevertheless, the IP Law only grants such protection in respect of plant varieties that are on the list of State-protected plant species promulgated by the Ministry of Agriculture and Rural Development (MARD). ${ }^{82}$ Once the plant variety protection certification is granted, it is valid

\footnotetext{
81 IP Law, Art. 157(1).

82 Ibid., Art. 158.
} 
throughout the territory of Vietnam. ${ }^{83}$ Plant variety protection certificates are valid from the grant date to the end of a period of 25 years for timber trees and vines, and 20 years for other plant varieties. ${ }^{84}$ The term of protection of plant varieties under the IP Law matches the duration of breeders' rights under the UPOV Convention. ${ }^{85}$ During the term of protection, any exploitation or use of the rights of a protection certificate holder without his or her permission, or of a plant variety denomination that is identical or similar to a denomination protected for a plant variety of the same species or a species closely linked to the protected plant variety, or of a protected plant variety without payment of remuneration shall be regarded as infringement. ${ }^{86}$ Based on the seriousness as well as the nature of the infringement, administrative or criminal and civil remedies may be pursued against the infringer. ${ }^{87}$

In June 2019, the Vietnamese National Assembly ratified a law amending and supplementing the IP Law, with the aim of bringing it into line with the terms of the Comprehensive and Progressive Agreement for Trans-Pacific Partnership (CPTPP), which entered into force on 14 January $2019 .{ }^{88,89}$ The key changes in the amended IP Law concern patents, trademarks, geographical indications and enforcement of intellectual property rights. Nonetheless, no issues related to new plant varieties or the farmer's privilege exemption were addressed under the amendment.

\subsubsection{The International Union for the Protection of New Varieties of Plants 1991}

In 2006 Vietnam became an official member of the UPOV Convention 1991. The UPOV Convention's goal is to provide and promote an effective system of protection of plant varieties. ${ }^{90}$ The Convention sets the international rules to be followed by its Contracting Parties in granting exclusive rights to the breeders of new plant varieties. ${ }^{91}$ In other words, it facilitates trade in new plant varieties and contributes to global agricultural production activities. ${ }^{92}$ The UPOV Convention regulates the protection of new varieties of plants that are distinct, uniform and stable. $^{93}$ The protection of new plant varieties under the UPOV Convention is

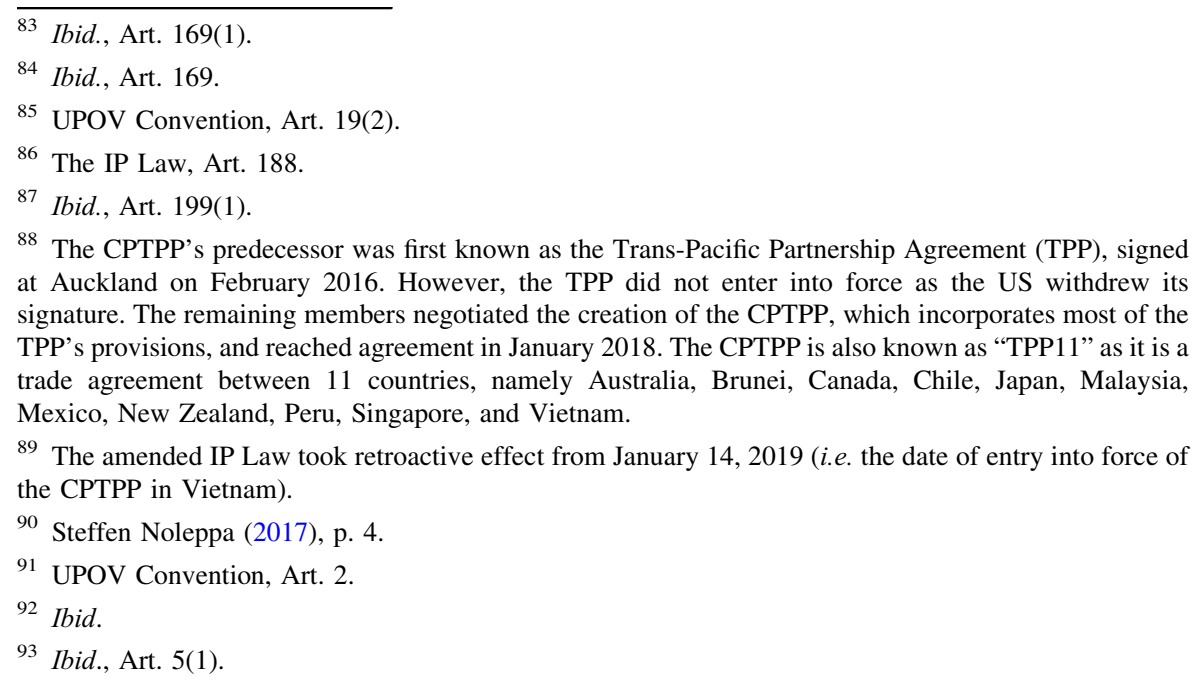


carried out under a sui generis system as referenced under Art. 27.3.b of the TRIPS Agreement. This system is an alternative regime that allows countries to protect the plant varieties in a way that departs from the traditional patent-based system.

The UPOV Convention protects the commercial interests of breeders in consideration of their contribution to the creation of new plant varieties. However, in order to harmonize the rights and benefits of breeders and farmers, the Convention also contains many exemptions, of which farmer's privilege is one. The provisions contained in the Convention on farmer's privilege form the foundation of Vietnam's IP Law as well as of comparable laws in many developing countries.

Vietnam joined the UPOV Convention as a transitional step before becoming an official member of the WTO. Becoming a Contracting Party of the UPOV Convention was intended to facilitate the promotion of domestic plant varieties and the creation of a fair environment for developing seeds and plant varieties among Vietnamese and foreign individuals and organizations. After more than a decade as a member of the UPOV Convention, Vietnam has recorded some achievements. The country has recorded an increase in breeding activities, which contribute to and enhance efforts towards the diversification of domestic and imported plant varieties. ${ }^{94}$ The abundance of plant varieties has strengthened the industry's competitiveness, which promotes and contributes to development of the country's agricultural sector. ${ }^{95}$ These achievements are also reflected in the rise in the number of applications submitted for breeders' rights protection, as well as an increase in the annual rate of agricultural production. ${ }^{96}$ Farmers' yearly income has increased by more than $24 \%$ since Vietnam joined the UPOV Convention. ${ }^{97}$ However, there has been little study on the impact of the farmer's exemption under the UPOV Convention on Vietnamese farmers.

\subsubsection{TRIPS Agreement}

In January 2007 Vietnam became an official member of the WTO and joined the TRIPS Agreement. The TRIPS Agreement is a comprehensive multilateral agreement on intellectual property, ${ }^{98}$ under which WTO members are required to provide a minimum level of intellectual property protection in their national laws. ${ }^{99}$ In respect of new plant varieties, it is necessary to have a legal framework that protects breeders' achievements and economic benefits in this sector. In light of this, the TRIPS Agreement highlights the need to provide a level of intellectual property protection for new plant varieties. Although there are no concrete provisions in the Agreement for the protection of plant varieties, Art. 27.3(b) requires members to adopt the best regime for the protection of plant varieties in their national laws.

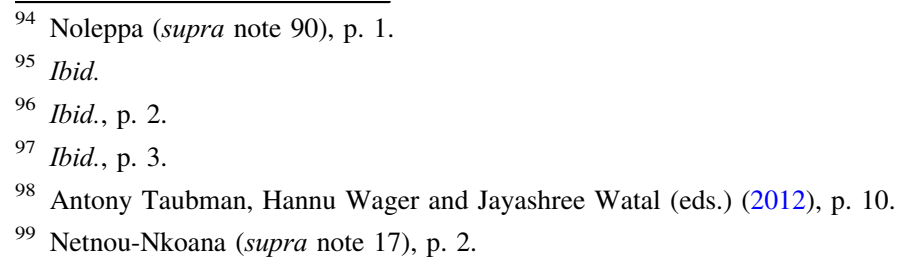


Specifically: “... Members shall provide for the protection of plant varieties either by patents or by an effective sui generis system or by any combination thereof."100

The TRIPS Agreement suggests three possible regimes that its members can consider in order to protect plant varieties in their countries, namely patents, a sui generis approach, or a combination of the two. Choosing a suitable national regime to protect plant varieties entirely depends on each nation, based on their socioeconomic conditions. Members can choose a single regime or even a dual protection regime involving both breeders' rights and patent rights. The wording of Art. 27.3(b) does not prohibit a country from creating its own regime governing the protection of plant varieties as long as that regime does not infringe any basic rules of protection of intellectual property rights under the TRIPS Agreement and other agreements. This provision complies with the national discretion laid down in Art. 1 (1) of the TRIPS Agreement, which reads:

... Members may, but shall not be obliged to, implement in their law more extensive protection than is required by this Agreement, provided that such protection does not contravene the provisions of this Agreement. Members shall be free to determine the appropriate method of implementing the provisions of this Agreement within their own legal system and practice.

Interestingly, different WTO members have different understandings of the wording of Art. 27.3(b). In particular some members need clarification of the term "effective sui generis system."101 To deal with this situation, members should ensure the legal protection of plant varieties, the sale and exchange of seeds, and the system of self-saving, regardless of the sui generis system used. This is essential in order to safeguard the prosperity of rural and local communities and achieve food security. ${ }^{102}$

From the options available under the TRIPS Agreement, Vietnam elected to protect plant varieties by means of a sui generis system. Therefore, as a WTO member, Vietnam has had to adopt effective regulations under its national laws to ensure enforcement of the intellectual property rights as required by the TRIPS Agreement. ${ }^{103}$ Nevertheless, Vietnam needs to take further action to secure adherence to and enforcement of its legal instruments in order to meet its obligations under international trade agreements.

\subsection{6 СРТРP}

Vietnam is a member of the CPTPP, which aims, inter alia, to provide free market access among its members. Intellectual property rights are mentioned in Chapter 18 of the CPTPP, which requires its members to accede to other supplementary

\footnotetext{
100 TRIPS Agreement, Art. 27(3)(b).

101 WTO (supra note 3), p. 47.

102 Ibid.

103 TRIPS Agreement, Art. 41(1).
} 
agreements (in the event they were not yet parties to them), one of which being the UPOV Convention, before the entry into force of the CPTPP. ${ }^{104}$

By referring the UPOV Convention as a source of law, the CPTPP creates favorable conditions for its members, by harmonizing the regulation of plant variety protection, especially considering the developmental asymmetry in the members' legal, economic, political and social environments. The CPTPP contains no provisions on farmer's privilege. However, this omission can be resolved by relying on the provisions of the UPOV Convention to resolve disputes relating to farmer's privilege and breeders' rights among members.

In summary, although Vietnam meets the standards required under the various international agreements of which it is a signatory, more work is still needed with regard to intellectual property right protection of plant varieties. Specifically, an approach that is better tailored to national circumstances is required in respect of provisions governing the farmer's privilege exemption, as the one-size-fits-all approach adopted conflicts with the country's developmental goals. The importance of safeguarding farmers' rights comes to the fore given the agricultural strength of other CPTPP signatories such as Australia, New Zealand and Japan. Applying a tailored farmer's privilege regulation will be beneficial not only for Vietnamese farmers, but also in terms of achieving the country's development objectives.

\subsubsection{The European Union-Vietnam Free Trade Agreement}

The Free Trade Agreement between Vietnam and the European Union (EVFTA) has been concluded, after three years of negotiations. ${ }^{105}$ The Agreement took effect from the beginning of August 2020, after ratification by all the participating countries. ${ }^{106}$ The EVFTA aims to "boost bilateral exchange in goods and services and create substantial gains for European retailers sourcing from and investing in Vietnam."107 Article 12(42) of the EVFTA states as follows:

The Parties shall protect plant varieties rights, in accordance with the International Convention for the Protection of New Varieties of Plants ... including the exceptions to the breeder's right as referred to in Article 15 of this Convention, and cooperate to promote and enforce these rights.

The EVFTA accordingly recognizes farmer's privilege when referring to the exception to breeders' right under the UPOV Convention. Therefore, the wording used in the EVFTA employs the UPOV Convention as a legal tool or dispute resolution instrument when it pertains to the protection of plant varieties. This assists the Parties in interpreting and implementing the applicable regulations.

\footnotetext{
104 CPTPP, Art. 18(7).

105 EuroCham, Whitebook 2017: Trade \& Investment Issues and Recommendations, p. 2.

106 According to Art. 17(16)(2) of the EVFTA this Agreement "shall enter into force on the first day of the second month following the month during which the Parties have notified each other of the completion of their applicable legal procedures for the entry into force of this Agreement".

107 Foreign Trade Association, Insight on EU-Vietnam Free Trade Agreement, February 2016, p. 2.
} 
The EVFTA is expected to create significant advantages for both parties, especially for Vietnam's agricultural sector, which will gain free access to the EU market, following the elimination of tariffs of goods among the Parties. ${ }^{108}$ To take full advantage of this opportunity, Vietnamese farmers should adapt their traditional farming practices to adhere to regulations on food safety and hygiene, starting with respecting breeders' rights and taking advantage of the farmer's privilege regulation. The Vietnamese Government should develop more supportive policies to instruct and assist its farmers.

\subsection{Farmer's Privilege Under Vietnam's IP Law}

The farmer's privilege exemption under the IP Law means "using harvested materials of protected plant varieties by individual production households for selfpropagation and cultivation in the next season on their own land areas."109 Individual production households that save seeds for the next season on their own holdings do not infringe breeders' rights. ${ }^{110}$ However, the IP Law contains no further explanation of the farmer's privilege exemption or of permissible acts in terms of making use of plant varieties. It also remains silent on the possibility of exchanging seeds among farmers. Article 12 of Decree $31 / 2016^{111}$ lists the activities that are considered to infringe breeders' rights, which excludes seed exchange between farmers. ${ }^{112}$ If farmers exchange protected plant varieties, as was historically common practice for unprotected seeds, do they infringe the breeder's right under the IP Law? Article 12 of Decree 31/2016 is also unclear on other issues, such as seed offering and selling. What will happen if a farmer, who cannot make use of his or her own holding due to a natural disaster, sells saved seeds to another farmer that has a smallholding $?^{113}$ In this case, does the seed seller infringe the breeder's rights? In other words, to what extent can the sale of protected varieties be considered to infringe the IP Law? The explanation of "performing of activities for

\footnotetext{
$\overline{108}$ The aim is to eliminate $99 \%$ of tariffs within seven years. This should result in $€ 15$ billion a year in additional exports from Vietnam to the EU by 2035, while EU exports to Vietnam would expand by $€ 8.3$ billion annually, See EU-Vietnam trade deal: what are the benefits? Available at: https://www.europarl. europa.eu/news/en/headlines/economy/20200131STO71518/eu-vietnam-trade-deal-what-are-the-benefits (accessed 20 June 2020).

109 IP Law, Art. 190(1)(d).

110 Ibid.

111 Decree No. 31/2016/ND-CP of May 6, 2016, of the Government on Penalties for Administrative Violations in the field of Protection of Plant Varieties and Plant Quarantine (hereinafter Decree 31/2016).

112 Decree 31/2016, Art. 12(2) (violations against regulations on breeder's rights) includes the following acts: production or propagation, treatment for propagation purpose, offering (to sale), sales or performance of activities for access to the market, import and export.

113 For natural disaster circumstances, Malaysia, a Contracting Party of the UPOV, regards farmer's privilege as having a broader scope, covering "any exchange of reasonable amount of propagating material among small farmers; and the sale of farm-saved seeds in situation where a small farmer cannot make use of the farm-saved seeds on his own holding due to natural disaster or emergency or any other factor beyond the control of the small farmer, if the amount sold is not more than what is required in his own holding." Protection of New Plant Varieties Act 2004 of Malaysia, Art 30(1)(e) and (f).
} 
access to the market" contained in Decree 31/2016 is insufficient. In cases of conflict as mentioned above, it is difficult for the competent authorities to resolve these issues by applying the IP Law and its guidance regulations. This is contrary to the policy of judicial reform set out by Resolution No. $48 .^{114}$

The issues relating to farmer's privilege that are addressed in the UPOV Convention and its instruments, such as the usage of self-saved seeds (i.e. for propagating on a farmer's own holdings, not for trade, exchange), farm size, type of variety and own holdings are not currently problematic in Vietnam. The common practice of applying the self-saved seeds exemption is limited in Vietnam for the following reasons:

First, small farms are in the majority in Vietnam. Because of the high density of the Vietnamese population, ${ }^{115}$ the average land area for rice growing farms and households is not big, approximately 0.3 hectare in $2016 .{ }^{116}$ Average farm size in Vietnam is around 0.8 hectares, while large farms are those that are 2 hectares and above. $^{117}$ Large farms account for about $10 \%$ of agricultural land and most production of perennial crops takes place on them. ${ }^{118}$ Small farmers tend to buy the seeds that are available on the market instead of saving seeds for next crops themselves. So far, no dispute has arisen between breeders and farmers concerning the self-saved seed exemption that has come to the attention of or been resolved by the court system or administrative agencies.

Second, there is a lack of proper policy to support research activities in creating new plant varieties, as evidenced by the low number of plant variety protection certificates that have been issued by the new Plant Varieties Protection Office in Vietnam. The number of certifications of plant variety protection granted from 2004 to 2015 to Vietnamese individuals and organizations was 170 , and the number granted to foreign individuals and organizations was 134 . $^{119}$ The IP Law provides that plant varieties are eligible for protection if they are new, distinct, uniform, stable, and designated by proper denominations. ${ }^{120}$ These criteria are identical to those laid down in the UPOV Convention.

\footnotetext{
114 In 2005, the Politburo of the Central Committee Communist Party of Vietnam passed Resolution No. 48, "Strategy for the Development and Improvement of Vietnam's Legal System to the Year 2010 and Direction for the Period up to 2020" to make improvements to the national legal system. This Resolution aims for a modern transition to the rule of law and a market-based economy and sets out a strategy to develop and improve Vietnam's laws in terms of application and execution by 2020.

115 According to the World Bank's data, the population density of Vietnam in 2016 was 299 people per sq. km. See https://data.worldbank.org/indicator/EN.POP.DNST (accessed 5 April 2020).

116 General Statistic Office of Vietnam, Press release on the official results of the Rural, Agricultural and Fisheries Census in 2016, available at https://www.gso.gov.vn/Default.aspx?tabid=382\&ItemID=18591 (accessed 5 April 2020).

117 OECD (2015), Agricultural Policies in Vietnam 2015, OECD Publishing, Paris, p. 24, available at http://dx.doi.org/10.1787/9789264235151-en (accessed 5 April 2020).

118 Ibid.

119 Statistic certification from 2004-2015 can be found at the website of the MARD, available at http:// pvpo.mard.gov.vn/ByApplicant.aspx (accessed 5 April 2020).

120 IP Law, Art. 157.
} 
In addition, the plants must be "on the list of State protected plant species promulgated by the MARD." It is notable that in 2007 the MARD issued Decision 95/2007, 121 "Regulations on recognition of new agricultural plant varieties," which prescribes the order and procedures applicable to testing, trial production, recognition and naming of new agriculture plant varieties. ${ }^{122}$ Under Decision $95 / 2007$, only new agricultural plant varieties that satisfy the tests required by the MARD - such as official testing, breeder testing, distinctness, uniformity and stability (DUS) testing, and value of cultivation and use (VCU) testing - can be imported into or recognized in Vietnam. ${ }^{123}$ The plant variety must also comply with State policy on intellectual property because the State "will not protect intellectual property objects which are contrary to the social ethics and public order and prejudicial to defense and security."124

In 2008, the MARD issued Decision $35 / 2008^{125}$ requiring farm households to register plant varieties and have their rights protected under the IP Law when they take part in research projects that are approved and organized by the provincial People's Committees. This decision encouraged farm households to produce and exchange plant varieties in the community and circulate them on the market. ${ }^{126}$ Decision 35/2008 set the legal and administrative procedures for the government to grant financial support to farm households in using, improving, and exploiting local traditional crop varieties. To some extent, Decision 35/2008 evidenced the government's endeavors in encouraging the development of plant varieties research in Vietnam. In Vietnam, the average time to create a new type of variety is about 10 to 24 years, depending on the species. ${ }^{127}$ Decision $35 / 2008$, however, only applied from 2006 to 2010. Its duration of application was therefore too short to yield proper results and was, in particular, an insufficient period in which to carrying out production testing in relation to long-term plants pursuant to Decision 95/2007. The timeframe required from trial production to official recognition of a plant variety under Decision 95/2007 was three years for short-term plants and seven for longterm plants. ${ }^{128}$ Creating a new plant variety is complex because it requires a great deal of technical input and effort from breeders. Therefore, without sufficient financial and technical support, most small farmers will be unable to satisfy the requirements of the DUS and VCU tests. ${ }^{129}$

The MARD could have provided farmers with greater assistance in meeting these requirements because, under Decision 35/2008, its task was to encourage farmers to

\footnotetext{
121 Decision No. 95/2007/QĐ-BNN dated 27 November 2007 re: Regulation on recognition of new agricultural plant varieties (hereinafter Decision 95/2007).

122 Ibid., Part 1, Art. 1.

123 Decision 95/2007, Art. 2(1)-(5).

124 The IP Law, Art. 8(1).

125 Decision No. 35/2008/QĐ-BNN dated 15 February 2008 re Regulations on Production Management of Farm Households' Plant Varieties (hereinafter Decision 35/2008).

126 Ibid., Art. 1(1).

127 Louwaars et al. (supra note 5), p. 16.

128 Decision 95/2007, Art. 9(3).

129 Nguyen Thi Ngoc Hue et al. (2016), p. 82.
} 
effectively maintain, preserve and exploit the genetic resources of local plants and new plant varieties. ${ }^{130}$ Accordingly, a governmental financial budget was allocated to support testing, trial production, new plant variety recognition and registration of new plant varieties developed by farm households. ${ }^{131}$ Had Decision 35/2008 been in force for a longer period, this would have helped to achieve more remarkable results and improved the number of plant varieties created by farmers. However, due to the complexity of the registration process for plant varieties, and the lack of support provided in relation to it, the country has recorded low numbers of applications and certifications.

Third, the time it takes to obtain certifications for plant variety protection is a significant obstacle. This delay is not only a factor in processing applications for new plant variety protection, but also in relation to applications for licenses to produce and trade plant varieties in Vietnam, which is mandatory under Decision 95/2007. The procedure to be followed in order to register seeds and plant varieties is also complex and can take up to three years. In contrast, seeds do not need to be registered in Thailand and the Philippines, and the registration procedure only takes only up to 1.5 years in Indonesia. ${ }^{132}$ This creates a hindrance for Vietnam's agricultural sector and puts it at a disadvantage compared to neighboring countries. The failure to address the issue of excessively lengthy procedures contradicts the Prime Minister's aim, expressed in the Intellectual Property Strategy by 2030, of ensuring "fast, transparent, fair and timely response to the requirements of enterprises and society." 133

\section{Recommendations}

\subsection{Learning from the EU Commission Regulations on Plant Varieties}

The EU relied on the UPOV Convention to create its own legal system on the protection of plant varieties and applies it effectively and flexibly within the EU. The EU regulations on plant variety rights are explicitly designed to protect farmers, and cover such issues as level of remuneration, the rights of small farmers and monitoring of farmers. ${ }^{134}$ Meanwhile, the significance of the farmer's privilege exemption remains law on paper in Vietnam. Vietnam should consider perfecting its regulations on the protection of farmer's rights, which could be achieved by implementing the substance of the UPOV Convention's guidelines on the issue of farmers' holdings.

The UPOV Explanatory Notes clarify that the optional exception in respect of a farmer's holding is restricted to the following permission: "farmers to use for

\footnotetext{
${ }^{130}$ Decision 35/2008, Art. 3.

131 Ibid., Art. 7(2).

132 OECD (2015) (supra note 117), p. 209.

133 Decision No. 1068/QD-TTg on approving the Intellectual Property Strategy until 2030 dated 22 August 2019.

${ }^{134}$ Implementing Regulation, Arts. 4, 5, 7 and 14.
} 
propagating purpose, on their own holdings, the product of the harvest which they have obtained by planting, on their own holdings, the protected variety ...". [emphasis added] ${ }^{135}$

Through the added emphasis, the UPOV Explanatory Notes clarify that farmer's privilege only applies to those farmers who plant propagated seeds that are obtained and harvested from their own farmland. Therefore, the exemption does not extend to farmers who propagate materials produced on the holding of another farmer. ${ }^{136}$ However, the clarification on farmer's holding in the UPOV Explanatory Notes remain unclear in respect of certain situations. The following scenarios suggest possible areas that could benefit from greater clarity in the UPOV Explanatory Notes:

(i) Transfer of ownership of a holding from a farmer to farmer(s). If the ownership of a holding is transferred, is it possible for the new farmer(s) to obtain, trade, exchange or use seeds that were saved by the previous farmer? Does this mean that when a farmer's ownership of a holding is terminated, his or her privilege also ends? If the answer to this is affirmative, then the nature of the farmer's holding should be clarified by stating that "the exception will not be applied when the ownership of the holding is transferred."

(ii) Leasing the holding to other farmer(s). Is a clause in a lease agreement under which it is agreed that the lessee(s) may obtain, use, trade or exchange seeds that the lessor has saved for propagation on his or her own holding in previous crops valid? In this situation, the farm's ownership would not have changed but the lessee(s), not the lessor, is planting on the lessor's holding.

(iii) The situation in which a farmer allows another farmer to use his or her farmland (partially or entirely) to grow plants, with or without benefits being given in return, for a specific time period. Would it be possible for the previous farmer to obtain seeds from, or trade or exchange them with, the new farmer on the same holding? In this situation, ownership of the holding remains unchanged. For that reason, would it be regarded as their own holding if the farmer has not actually grown the plant him or herself on his or her own holding? Would the UPOV exception apply in such a situation?

Vietnam should consider the issues discussed above when perfecting its regulations on farmer's holding in its IP Law. In addition, given the significance of the term "on their own holdings," in which circumstance use of saved seeds is legal, it should be explained in greater detail. As analyzed above, the EU Implementing Regulation is more advanced than the UPOV Explanatory Notes on exceptions to breeders' rights. This is especially the case given that the meaning of "their own holdings" varies from situation to situation (e.g. transfer of ownership or lease of the holding and where the farmer is not directly growing plants him or herself). The Implementing Regulation specifies that an "own holding shall be considered to be any holding or part of a holding, which the farmer exploits for plant

\footnotetext{
$\overline{135}$ UPOV Explanatory Notes, para. 24.

136 Ibid.
} 
growing, whether as his property or leasehold."137 The Implementing Regulation provides that "transfer" covers both transfer of the holding and disposal of a holding or part thereof for the purpose of exploitation by others, and that on transfer of a holding the farm-saved seed may not be the object of a transfer to other. ${ }^{138}$ Although the Implementing Regulation was enacted 15 years before the UPOV Explanatory Notes were published, its scope is broader because the purposes of these documents differ. Farmer's privilege under the UPOV Convention and UPOV Explanatory Notes aims to protect the legitimate benefits of breeders, while the Basic Regulation and Implementing Regulation are designed to protect the legitimate interests of society as a whole, as well as farmers, not only breeders. Consequently, Vietnam should aim to identify the domestic issues that arise from the understanding of the concept of own holdings and draw lessons from the EU's Implementing Regulations to perfect the regulation of farmer's privilege in the country. The clarity of the IP Law in relation to farmer's privilege will contribute to the full actualization of farmer's rights and benefits.

\subsection{Amendment of the IP Law}

\subsubsection{Exchange of Saved Seeds}

The IP Law and other related documents are silent on the possibility of the seeds of protected varieties being exchanged among farmers. This may pose a hindrance for the courts and administrative agencies tasked with resolving cases in which farmers exchange saved seeds among themselves. For this reason, it is of paramount importance that the IP Law and its documents be clear on such issues. Can farmers exchange their saved seeds among themselves? If so, to what extent is this legally permissible? If they cannot, then this must be addressed explicitly and regulated either by the IP Law itself or in supplemental documents. The IP Law provides that "where a treaty to which the Socialist Republic of Vietnam is a contracting party contains provisions different from those of this Law, the provisions of such treaty shall apply,"139 pursuant to which the UPOV Convention (Art. 15(2)) should prevail. However, the requirement "to permit farmers to use for propagating purpose, on their own holdings the product of the harvest which they have obtained by planting" set out in the same provision is an exception. For that reason, Vietnam's IP Law must be expressed in such a way as to avoid misunderstanding regarding the possibility of exchanging saved seeds among farmers.

\subsubsection{Clarify the Acts of Use}

The IP Law does not specify acts of use in relation to protected plant varieties but one of its documents, Decree 31/2016, does. Accordingly, if a person makes use of farm-saved seeds, for example, by offering them for sale or carrying out activities in

\footnotetext{
137 Implementing Regulation, Art. 4(2).

138 Ibid., Art. 4(1) and (2).

139 The IP Law, Art. 5(3).
} 
relation to access to the market (in order to sell the saved seed) without being entitled to do so, he or she is considered to have infringed the breeder's rights and shall be fined an amount ranging from US\$1,720 to US\$2,150. ${ }^{140}$ Although the acts that Decree 31/2016 describe reflect precisely the wording used in Art. 14(1) of the UPOV Convention, further guidance is needed as to the degree of seriousness of infringing acts and their impact on breeders that is required in order to trigger the application of a penalty. If these acts have not yet infringed the breeder's right, the seeds have already been confiscated and no actual damage has occurred, is it necessary to impose a monetary fine on the infringer? ${ }^{141}$ If a farmer sells a small amount of self-saved seeds to his neighbor, would he or she be subject to the same penalty as those who sell seeds on a large scale for a commercial purpose? If a farmer gives, free of charge and for humanitarian purposes, his or her own saved seeds of protected varieties to neighbors after the village has suffered from a natural disaster, would that constitute infringement of the breeder's right? These questions should be addressed by amending the IP Law in light of the exception created by the UPOV Convention, in order to protect the rights of Vietnamese farmers. This is extremely important given that many Vietnamese farmers know little either about breeders' intellectual property rights or about farmer's privilege. ${ }^{142}$

\subsection{Amendment of the Penal Code}

Under the TRIPS Agreement, members are required to have in place enforcement regulations including judicial and administrative remedies, as well as border measures and criminal procedures. ${ }^{143}$ For that reason, the IP Law stipulates that "organizations and individuals that have committed acts of infringement of other's intellectual property rights are liable to civil, administrative or criminal remedies, depending on the nature and extent of such infringement." ${ }^{144}$ However, the Penal Code of $2015^{145}$ contains no provisions regulating infringement of plant variety rights, although it does contain provision on copyright infringement ${ }^{146}$ and on infringement of industrial property rights. ${ }^{147}$ In other words, breeders' rights of breeders are not protected under the Penal Code of 2015. The WTO requires the protection of breeders' rights by means of criminal proceedings. However, due to the lack of relevant regulation in the Penal Code of 2015, no means of enforcement through Vietnam's criminal court system are available in respect of this issue. Where a new variety is sold commercially without the breeder's consent in Vietnam, his or her rights are only protected by administrative

\footnotetext{
${ }^{140}$ Decree 31/2016, Art. 12(2).

141 Ibid., Art. 12(4).

142 Nguyen Thi Ngoc Hue (supra note 129), p. 81.

143 TRIPS Agreement, Arts. 41-61.

144 IP Law, Art. 199(1).

145 The Penal Code was passed by the 13th National Assembly of the Socialist Republic of Vietnam, at its 6th session on 27 November 2015 and entered into force as of 1 January 2018 (hereinafter Penal Code 2015).

146 Penal Code 2015, Art. 225.

147 Ibid., Art. 226.
} 
remedies. The criminal courts must refuse to hear such cases because one of the bases of criminal liability is the principle nulla poena sine lege, accordingly "no one who commits a criminal offence that is not regulated by the Penal Code has to incur criminal liability." 148 The absence of breeders' rights in the Penal Code of 2015 is a big loophole that Vietnam needs to address promptly in order to meet its commitments as a WTO member. This is not only an obligation under the TRIPS Agreement, but also under other bilateral and multilateral trade agreements to which Vietnam is a party. Currently, any dispute related to plant variety must be heard by an administrative court or be addressed via civil law proceedings in the same way as copyright and trademark infringement cases.

\section{Conclusion}

In order to enhance the value of its agricultural products, Vietnam should utilize the legal tools available to it, especially in terms of intellectual property regulations covering issues such as collective marks, certificate marks and geographical indications. ${ }^{149}$ The use of such regulations can boost "development from within", ${ }^{150}$ which will help farmers maximize profits from their land. When agricultural products are protected in this way not only farmers but also the State benefits. The current low level of awareness and interest on the part of farmers and local authorities about the importance of the role of collective marks, certificate marks and geographical indications, and the degree of involvement by local authorities in promotion $^{151}$ of the use of these intellectual property tools, should be improved in order to enhance the value of the agriculture products. Adequate performance of these tasks would markedly reduce the risk of food fraud.

Funding Open access funding provided by University of Eastern Finland (UEF) including Kuopio University Hospital.

Open Access This article is licensed under a Creative Commons Attribution 4.0 International License, which permits use, sharing, adaptation, distribution and reproduction in any medium or format, as long as you give appropriate credit to the original author(s) and the source, provide a link to the Creative Commons licence, and indicate if changes were made. The images or other third party material in this article are included in the article's Creative Commons licence, unless indicated otherwise in a credit line to the material. If material is not included in the article's Creative Commons licence and your intended use is not permitted by statutory regulation or exceeds the permitted use, you will need to obtain permission directly from the copyright holder. To view a copy of this licence, visit http:// creativecommons.org/licenses/by/4.0/.

\footnotetext{
148 Ibid., Art. 2(1).

149 There are 60 types of products designated as registered geographical indications in Vietnam as of December 2017 of which 40 are derived from plants. See also the List of protected GIs in Vietnam, National Office of Intellectual Property of Vietnam, available at http://www.noip.gov.vn/web/guest/chidan-dia-ly (accessed 10 June 2020).

150 Sarah Bowen (2010), p. 231.

151 Barbara Pick et al. (2017).
} 


\section{References}

\section{Books, articles}

Bowen S (2010) Development from within? The potential for geographical indications in the global south. World Intellect Prop 13:231-252

Coomes OT et al. (2015) Farmer seed networks make a limited contribution to agriculture? Four common misconceptions. Food Policy 56:41-50

Correa CM (ed) (2015) Plant variety protection in developing countries: a tool for designing a sui generis plant variety protection system: an alternative to UPOV 1991. APBREBES

Ekvad M (2018) The functioning of the community plant variety office board of appeal. In: Geiger C et al. (eds) Intellectual property and the judiciary. Edward Elgar Publishing, Cheltenham

EuroCham. Whitebook 2017: trade \& investment issues and recommendations

Foreign Trade Association (2016) Insight on EU-Vietnam free trade agreement, February 2016

Halewood M, Lapeña I (2016) Farmers' varieties and farmer's rights: challenges at the crossroads of agriculture, taxonomy and law. In: Halewood M (ed) Farmers' crop varieties and farmers' rights challenges in taxonomy and law. Routledge, Abingdon

Kochupillai M (2016) Promoting sustainable innovations in plant varieties. Springer, Berlin

Lee M (2008) EU regulation of GMOs: law and decision making for a new technology. Edward Elgar Publishing, Cheltenham

Louwaars $\mathrm{N}$ et al. (2009) Breeding business: the future of plant breeding in the light of developments in patent rights and plant breeder's rights. Centre for Genetic Resources, the Netherlands, Wageningen University and Research Center, Wageningen

Netnou-Nkoana NC et al. (2015) Understanding of the farmers' privilege concept by smallholder farmers in South Africa. S Afr J Sci 111(1/2):01-05

Nguyen TNH et al. (2016) Promoting policy support for the enhancement and marketing of farmers' varieties in Vietnam. In: Halewood M (ed) Farmers' crop varieties and farmers' rights challenges in taxonomy and law. Earthscan, London

Noleppa S (2017) The socio-economic benefits of UPOV membership in Vietnam: an ex-post assessment of plant breeding and agricultural productivity after ten years. HFFA Research Paper 03/2017

Parker S et al. (2002) Has the U.S.-Vietnam bilateral trade agreement led to higher FDI into Vietnam? Int J Appl Econ 2(2):199-223

Pick B et al. (2017) The use of geographical indications in Vietnam: a promising tool for socioeconomic development. In: Calboli I, Ng-Loy WL (eds) Geographical indications at the crossroads of trade, development, and culture. Cambridge University Press, Cambridge

Sanderson J (2017) Plants, people and practices: the nature and history of the UPOV convention. Cambridge University Press, Cambridge

Taubman A, Wager H, Watal J (eds) (2012) A handbook on the WTO TRIPS agreement. Cambridge University Press, Cambridge

WTO (2006) Review of the provisions of Article 27.3.(B) Summary of issues raised and points made, noted by the Secretariat IP/C/W/369/Rev.1, 9 March 2006

\section{Treaties, Instruments}

\section{International treaties}

The Trade-Related Aspects of Intellectual Property Rights Agreement

The International Union for the Protection of New Varieties of Plants Convention 1991

The International Treaty on Plant and Genetic Resources for Food and Agriculture

Recitals to the International Treaty on Plant Genetic Resources of Food and Agriculture

The US-Vietnam Bilateral Trade Agreement

The Comprehensive and Progressive Agreement for Trans-Pacific Partnership

The European Union-Vietnam Free Trade Agreement 
The Explanatory notes on exceptions to the breeder's right under the UPOV Convention adopted by the Council at its forty-third ordinary session on 22 Oct 2009

Council Regulation (EC) No 2100/94 of July 1994 on Community plant variety rights, OJ L 227/1

Council Directive 2002/55/EC of 13 June 2002 on the marketing of vegetable seed, OJ L 193/33

Commission Regulation (EC) No 1768/95 of 24 July 1995 implementing rules on the Agricultural exemption provided for in Article 14(3) of Council Regulation (EC) No 2100/94 on Community plant variety rights, OJ L 173/14

Commission Directive 2009/145/EC of 26 November 2009 providing for certain derogations, for acceptance of vegetable landraces and varieties which have been traditionally grown in particular localities and regions and are threatened by genetic erosion and of vegetable varieties with no intrinsic value for commercial crop production but developed for growing under particular conditions and for marketing of seed of those landraces and varieties, OJ L 312/44

\section{Vietnamese instruments}

The Penal Code was passed by the 13th National Assembly of the Socialist Republic of Vietnam, at its sixth session on November 27, 2015 and entered into force on January 1, 2018

The Law on Intellectual Property Law 2005 entered into force on July 1st, 2006, a number of its articles were amended in 2009 and 2019

Decree No. 31/2016/ND-CP of May 6, 2016, of the Government on Penalties for Administrative Violations in the field of Protection of Plant Varieties and Plant Quarantine

Decision No. 95/2007/QĐ-BNN dated November 27, 2007 re Regulation on recognition of new agricultural plant varieties

Decision No. 35/2008/QĐ-BNN dated February 15, 2008 re Regulations on Production Management of Farm Households' Plant Varieties

Decision No. 1068/QD-TTg dated August 22, 2019 on approving the Intellectual Property Strategy until 2030

\section{Cited cases}

C-509/10 Geistbeck, ECLI:EU:C:2012:416

C-242/14 Saatgut-Treuhandverwaltung, ECLI:EU:C:2015:422

C-305/00 Schulin, ECLI:EU:C:2003:218

C-336/02 Brangewitz, ECLI:EU:C:2004:622

C-59/11 Association Kokopelli, ECLI:EU:C:2012:447

\section{Websites}

EU-Vietnam trade deal: what are the benefits? https://www.europarl.europa.eu/news/en/headlines/ economy/20200131STO71518/eu-vietnam-trade-deal-what-are-the-benefits. Accessed on 20 June 2020

General Statistic Office of Vietnam (2020) Press release on the official results of the Rural, Agricultural and Fisheries Census in 2016. https://www.gso.gov.vn/Default.aspx?tabid=382\&ItemID=18591. Accessed on 5 April 2020

List of protected GIs in Vietnam, National Office of Intellectual Property of Vietnam. http://www.noip. gov.vn/web/guest/chi-dan-dia-ly. Accessed on 10 June 2020

OECD (2015) Agricultural Policies in Vietnam 2015. OECD Publishing, Paris, p 24. https://doi.org/10. 1787/9789264235151-en. Accessed on 5 April 2020

Phạm H (2020) Nông nghiệp Việt trước nguy cơ lệ thuộc nguồn giống nhập kh u [Vietnamese agriculture in danger of dependence on imported seed source]. http://cand.com.vn/Kinh-te/Nong-nghiep-Viettruoc-nguy-co-le-thuoc-nguon-giong-nhap-khau-459130/. Accessed on 5 March 2020 
Statistic certification from 2004-2015 can be found at the website of the MARD. http://pvpo.mard.gov. vn/ByApplicant.aspx. Accessed on 5 April 2020

UPOV (2020) Mission Statement. http://www.upov.int/about/en/mission.html. Accessed on 5 May 2020 World Bank's data, the population density of Vietnam in 2016 was 299 people per sq km. https://data. worldbank.org/indicator/EN.POP.DNST. Accessed on 5 April 2020

Publisher's Note Springer Nature remains neutral with regard to jurisdictional claims in published maps and institutional affiliations. 